\title{
Endothelial Nitric Oxide Synthase (Enos) 4b/A Gene Polymorphism And The Risk Of Diabetic Nephropathy In Type 2 Diabetes
}

\author{
lectur. Lamees M.Al-Janabi \\ lamees-m@utq.edu.iq \\ Asst. Prof. Dr. Abdul Hussain A. Algenabi \\ lectur. Ahmed J. Mohammed
}

\begin{abstract}
$\underline{\text { Abstract }}$
Diabetic Nephropathy (DN) poses a major health problem. There is strong evidence for a potential role of the eNOS gene. The aim of this case control study was to investigate the possible role of genetic variants of the endothelial Nitric Oxide Synthase (eNOS) gene(VNTR) in the pathogenesis of nephropathy in patients with diabetes mellitus. The study included 196 subjects (145 T2DM and 51 normal control) T2DM were classified into 2 groups: 97 diagnosed with DN, and 48 diabetic without nephropathy and hypertension as +ve control. randomly selected was conducted to assess the association of SNP eNOS intron 4a/b VNTR polymorphism gene with diabetic nephropathy in Iraqi population. Blood samples from subjects and controls were analyzed to investigate the eNOS genotypes No significant differences were found in the frequency of eNOS genotypes between diabetic patients (either in group 1 or group 2 ) and controls ( $p>0.05$ ). Also, no significant differences were found in the frequency of eNOS genotypes between group 1 and group 2 ( $p>0.05)$.
\end{abstract}

\section{$\underline{\text { Introduction }}$}

Diabetes is among the major causes of renal failure. $10-20 \%$ of fatalities in diabetic patients are related to renal failure $^{(1)}$. Type II diabetes and diabetic nephropathy are obviously chronic progressive disorders that are related to a group of genetic, lifestyle and environmental factors ${ }^{(2)}$.

The exact etiology is unknown, but hyperglycemia and high blood pressure are considered to contribute to diabetic nephropathy. Persistently high blood sugar or blood pressure levels are two factors that can damage the kidneys, making them incapable of filtering wastes and remove water from your $\operatorname{body}^{(3)}$.

It is a major cause of end-stage renal disease. There are glomerular hemodynamic derangements leading to glomerular hyper-filtration, causing glomerular damage as indexed by microalbuminurea. There is overt proteinuria, decreased glomerular filtration rate, and end-stage renal failure $^{(4)}$.

NO is a vasodilator molecule produced from its precursor L-arginine by a family of NO synthases (NOSs) ${ }^{(5)}$. The NO system is formed of three distinct NO synthase (NOS) isoforms, encoded by three distinct genes, including neuronal (nNOS or NOS-1), inducible(iNOS or NOS-2) and endothelial (eNOS or NOS-3). The 
Web Site: https://jmed.utq.edu.iq

Email:utjmed@utq.edu.iq

ISSN (Print):1992-92 18, ISSN (Online):1992-92 18

DOI: https://doi.org/10.32792/utq/utjmed/18/2/4

gene encoding eNOS is found on chromosome $7(7 \mathrm{q} 35-\mathrm{q} 36)$ and contains 26 exons with an entire length of $21 \mathrm{~kb}$ $(6,7)$.

NO takes part in control functions including regulation of hemostasis, fibrinolysis ,platelet and leukocyte inter play with the arterial wall, vascularture control, vascular smooth muscle cell proliferation and blood pressure regulatory mechanisms.

Imbalance in NO bioavailability have been shown to result in endothelial dysfunction, causing increased liability to atherosclerotic lesion progression, hypertension, hypercholesterolemia, diabetes mellitus, thrombosis and stroke ${ }^{(8,9)}$.

The eNOS gene has been thought of as a possible candidate gene to $\mathrm{DN}$ liability. The presence of eNOS polymorphisms might contribute to a decreased eNOS activity and a reduced NO level, and has been reported to be a potential factor in the pathogenesis and development of DN. This polymorphism consists of the two alleles of eNOS $4 \mathrm{a}$ with 4 tandem 27 repeats and eNOS $4 \mathrm{~b}$ with 5 repeats ${ }^{(10)}$.

The eNOS gene has 2 common alleles including 4 repeats (a) and 5 repeats (b) which form 2 homozygous (aa and bb) and 1 heterozygous (ab)genotypes ${ }^{(11)}$. Recently, the eNOS intron $4 \mathrm{a} / \mathrm{b}$ VNTR polymorphism has been shown to be related to changed plasma NO levels and responsible for alterations in the genetic regulation of blood nitrite and nitrate concentration and enzyme formation ${ }^{(12,13)}$.

Chr 7

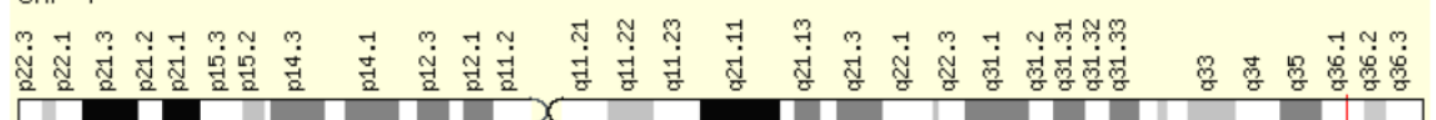

Figure 1 :Location of eNOS intron 4a/b VNTR gene in chromosome 7q3536 ${ }^{(14)}$

\section{Research Design and Methods}

A case-control study of 196 subjects (145 T2DM and 51 normal control) T2DM were classified into 2 groups: 97 diagnosed with $\mathrm{DN}$, and 48 diabetic without nephropathy and hypertension as +ve control. randomly selected was conducted to assess the association of SNP eNOS intron $4 \mathrm{a} / \mathrm{b}$ VNTR polymorphism gene with diabetic nephropathy in Iraqi population.

Inclusion criteria:

1. Those patients who were diagnosed by physicians as having type 2 diabetes, the criteria to diagnose diabetes were based on WHO guidelines.

2. A subject is said to have diabetes if his/her fasting glucose level was $>126 \mathrm{mg} / \mathrm{dl}$ (7.0 mmol/l) +symptoms of diabetes (polyuria, nocturia, polyphagia and weight loss).

3. Albuminuria $(>300 \mathrm{mg} / 24 \mathrm{~h}$ or $>200 \mu \mathrm{g} / \mathrm{min}$ or $>200 \mathrm{mg} / \mathrm{L}$ ) in two of three consecutive measurements on sterile urine samples-with or without renal 
ISSN (Print):1992-92 18, ISSN (Online):1992-92 18

DOI: https://doi.org/10.32792/utq/utjmed/18/2/4

failure (serum creatinine $>150$ to a mixture containing $0.2 \mu \mathrm{mol} / \mathrm{L}$ $\mu \mathrm{mol} / \mathrm{L})$.

4. Albumin/creatinine ratio $>2.5$ each of dATP, dCTP, dGTP, and

5. Age of patients was $>40$ years old.

Exclusion criteria.

1. Those diagnosed with T1DM.

2. congestive heart failure.

3. chronic kidney disease.

4. urinary tract infection.

5. Heamaturia.

6. acute febrile illness.

\section{Laboratory analysis}

Five milliliters of blood were taken from all subjects collected in two tubes, $2.5 \mathrm{ml}$ in plain tube without anticoagulants and $2.5 \mathrm{ml}$ in EDTA tube. After that, the serum tube centrifuged at $2000 \mathrm{xg}$ for approximately 10 minutes, the sera were aspirated and divided into two aliquots , and stored at $(-20 \mathrm{C})$ until time of use. The EDTA tube was used for extraction of DNA.

\section{DNA extraction}

Peripheral blood samples of patient and control groups were collected in EDTA tubes, and then DNA was extracted from whole-blood samples using Genomic DNA Mini Kit (Blood / cultured cell) (Geneaid) ${ }^{(15)}$.

The eNOS gene intron 4, 27 bp VNTR polymorphism was detected by polymerase chain reaction (PCR) according to the method described by Shah et al ${ }^{(237)}$. The template DNA (0.5 $\mu \mathrm{g}$ per sample) was amplified using the following primers: (forward) 5'-AGG CCC TAT GGT AGT GCC TTT-3' and 5'-TCT CTT AGT GCT GTG CTC AC-3' (reverse). These primers (10 pmol of each) were added dTTP; $5 \mu \mathrm{L}$ of $10 \times$ Cetus buffer $(\mathrm{pH}$ 8.3); $5 \mu \mathrm{L}$ of DMSO (100\%); and 0.5 units of Taq DNA Polymerase (Perkin Elmer Cetus), in a final volume of 20 $\mu \mathrm{L}$.

The PCR was initiated with a denaturation by first heating the samples for $5 \mathrm{~min}$ at $94{ }^{\circ} \mathrm{C}$. Thirty-five cycles of denaturation for $1 \mathrm{~min}$ at 94 ${ }^{\circ} \mathrm{C}$, annealing for $1 \mathrm{~min}$ at $56{ }^{\circ} \mathrm{C}$, primer extension for $2 \mathrm{~min}$ at $72{ }^{\circ} \mathrm{C}$, and a last extension for $5 \mathrm{~min}$ at $72{ }^{\circ} \mathrm{C}$ were applied for amplification. The PCR products of the NO gene locus were examined by gel electrophoresis (2\% NuSieve agarose-agarose) at $75 \mathrm{~V}$ for $120 \mathrm{~min}$ and visualized at room temperature under UV light after ethidium bromide staining.

Statistical analysis

Continuous variables expressed as mean $\pm \mathrm{SD}$ and Student's t-test was used to determine differences in means between control and T2DM groups. ANOVA test and Student's t-test was used to compare mean levels of continuous characteristics across genotypes using SPSS v. 20.0 software (SPSS Inc., Chicago, IL).Categorical data (genotypes and alleles) were expressed as frequency. In all statistical analysis the level of significance was $<0.05$.

Hardy-Weinberg equilibrium (HWE) is a mathematical relationship that related genotypes to allele frequencies $^{(16)}$. Genetic power was calculated using the online software OSSE \{online sample size estimator\} (osse.bii.a-star.edu.sg ${ }^{(17)}$ ). 
Web Site: https://imed.utq.edu.iq

ISSN (Print):1992-92 18, ISSN (Online):1992-92 18

DOI: https://doi.org/10.32792/utq/utjmed/18/2/4

\section{$\underline{\text { Results }}$}

\section{Age}

The diabetic and control groups were found to be matched in age. The distribution of age among the two groups was shown in figure 2.

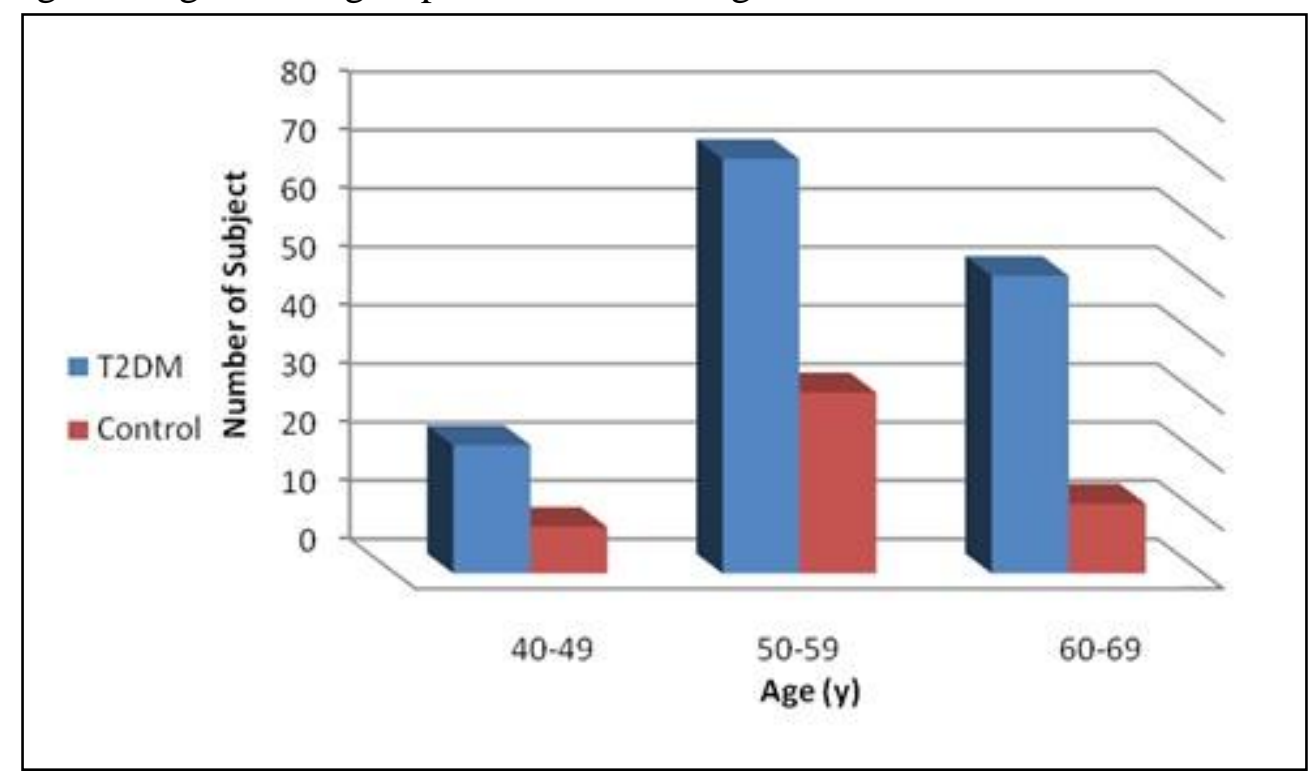

Figure 2: Age distribution of study subjects

\section{Gender}

The diabetic and control groups were found to be matched in gender. The distribution of gender among the two groups was shown in figure 3 .
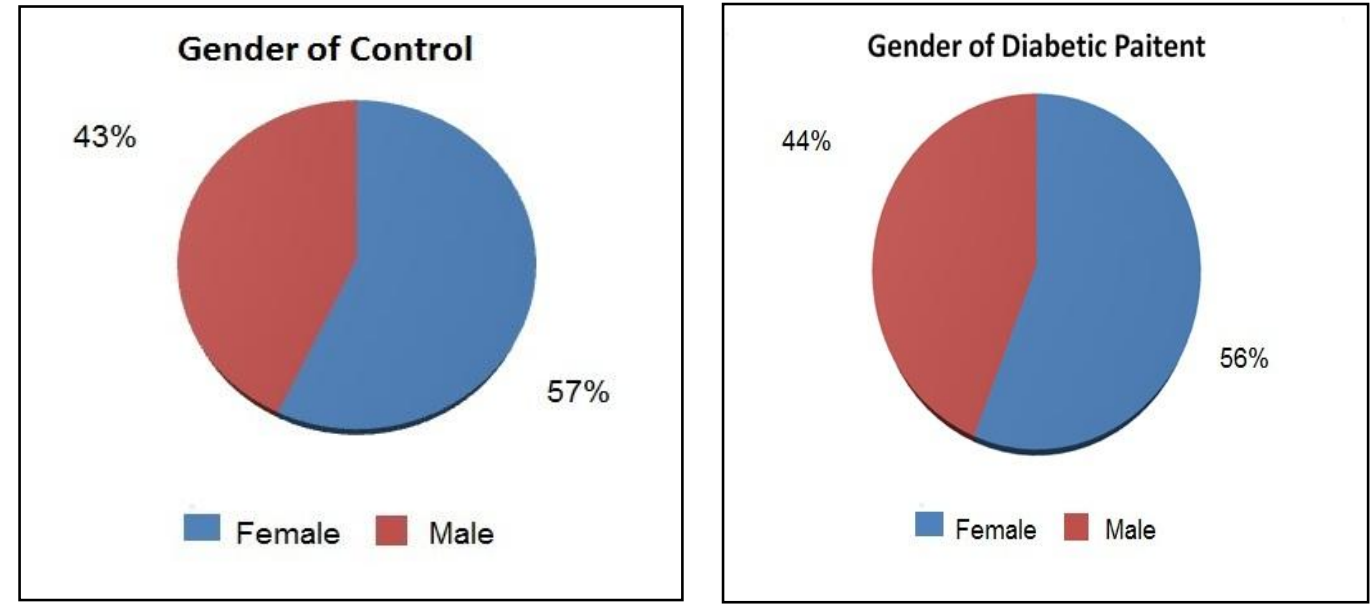

Figure3: Gender distribution of study subjects

Results of amplification reactions 
DOI: https://doi.org/10.32792/utq/utjmed/18/2/4

The amplification product of eNOS(VNTR) gene polymorphism i.e, the $4 \mathrm{a} / 4 \mathrm{~b}$ as described by Shah et al. ${ }^{(18)}$. Results were confirmed by agarose gel electrophoresis (figure 4 ).

\section{Figure 4: PCR product of DNA analyzed by agarose gel electrophoresis.}

DNA was extracted from blood,The PCR product was electrophoresed on $2 \%$ agarose (75V and $120 \mathrm{~min}$.) and directly visualized with ethidium bromide under UV light.

The PCR product of eNOS gene polymorphism were analyzed by agarose gel electrophoresis. Results demonstrated one ( 420 bp), one (393 bp) and two ( 420 , $393 \mathrm{bp}$ ) bands for those with wild type (bb), homozygous (aa) and heterozygous (ab) genotypes respectively (figure 5).

The overall power of the current study to detect a significant difference at level of 0.05 was estimated and found to be $79.9 \%$ for eNOS(VNTR) gene polymorphism. Genotype frequencies of eNOS(VNTR) were deviated from Hardy-Weinberg equilibrium in T2DM and control subjects $(\mathrm{P}<0.05)$.

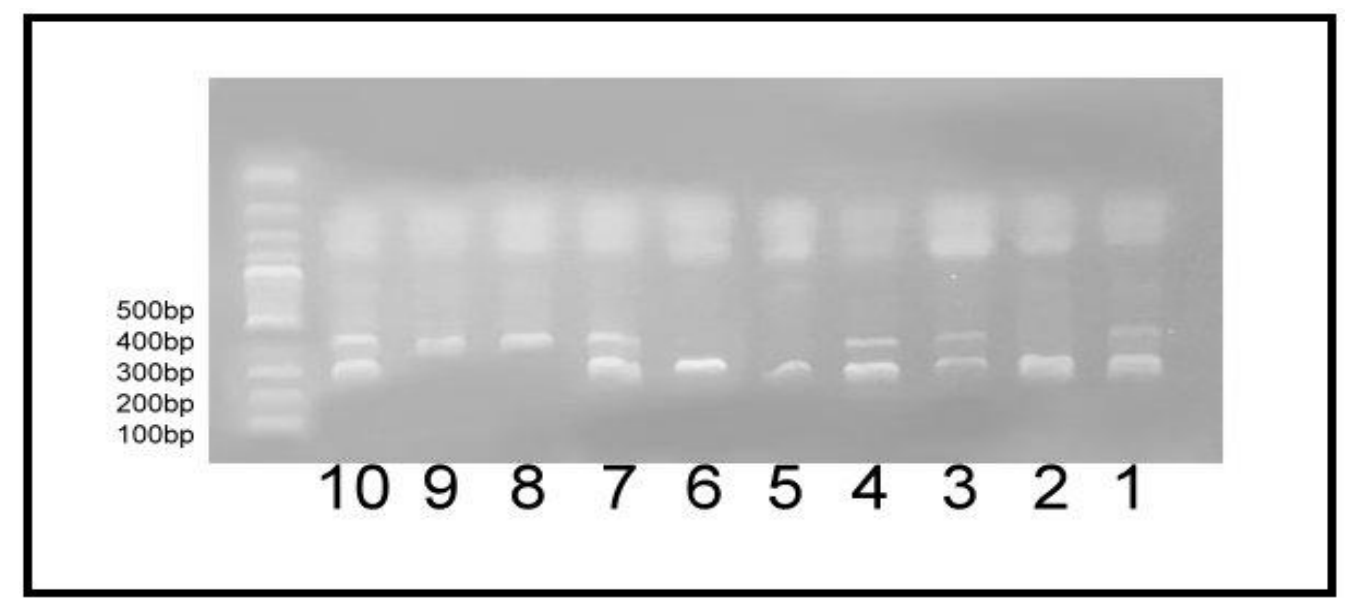


Web Site: https://imed.utq.edu.iq

ISSN (Print):1992-92 18, ISSN (Online):1992-92 18

Email:utjmed@utq.edu.iq

DOI: https://doi.org/10.32792/utq/utjmed/18/2/4

Figure 3.9. Results of eNOS gene polymorphism product on agarose gel electrophoresis. PCR product of eNOS gene were electrophoresed on $3 \%$ agarose $(75 \mathrm{~V}$ and120 min) and directly visualized with ethidium bromide under UV light.

Lines: DNA Marker

Lines 1, 3, 4,7,10 : ab genotype 420,390 bp

Lines $2,5,6$ :aa genotype $390 \mathrm{bp}$

Lines 8,9 :bb genotype 420 bp

Genotype and allele frequencies

To determine the genotyping error rate, a random duplication in $10 \%$ of the samples was reanalyzed. The concordance was obtained to be $100 \%$. The genotype and allele frequencies of eNOS gene polymorphism in T2DM with nephropathy and normal control subjects in codominant, dominant and recessive models were examined by

multinominal logistic regression analysis.

The genotype and allele frequencies of eNOS(VNTR) gene polymorphism in DN stated no significance association of DN with both normal control and diabetic control without nephropathy(table 1 and 2) respectively.

Table 1: Results of genotype and allele frequency of eNOS gene polymorphism in

\begin{tabular}{|c|c|c|c|c|c|c|}
\hline $\begin{array}{c}\text { eNOS } \\
(\mathrm{a} / \mathrm{b})\end{array}$ & $\begin{array}{r}\text { Control } \\
\text {-ve } n=51\end{array}$ & $\begin{array}{c}\mathbf{D N} \\
\mathbf{n}=97\end{array}$ & $\begin{array}{c}\text { Unadjusted } \\
\text { OR } \\
(95 \% \mathrm{CI})\end{array}$ & $\begin{array}{c}\mathbf{P} \\
\text { value }\end{array}$ & $\begin{array}{l}\text { Adjusted } \\
\text { OR } \\
(95 \% \text { CI })\end{array}$ & $\begin{array}{c}\mathbf{P} \\
\text { value }\end{array}$ \\
\hline \multicolumn{7}{|l|}{ Codominant } \\
\hline bb(Reference) & 19 & 16 & & & & \multirow[b]{2}{*}{0.14} \\
\hline $\mathrm{Ab}$ & 18 & 56 & $\begin{array}{c}0.53 \\
(0.2-1.2)\end{array}$ & 0.13 & $\begin{array}{c}0.53 \\
(0.2-1.2)\end{array}$ & \\
\hline $\mathrm{Aa}$ & 13 & 25 & $\begin{array}{c}1.3 \\
(0.5-3.3)\end{array}$ & 0.57 & $\begin{array}{c}1.68 \\
(0.6-4.4)\end{array}$ & 0.29 \\
\hline \multicolumn{7}{|l|}{ Dominant } \\
\hline$a a+a b$ (Reference) & 17 & 40 & $\begin{array}{c}0.7 \\
(0.3-1.5)\end{array}$ & 0.5 & $\begin{array}{c}0.8 \\
(0.3-1.4)\end{array}$ & 0.4 \\
\hline \multicolumn{7}{|l|}{ Recessive } \\
\hline$a b+b b($ Reference $)$ & 41 & 75 & & & & \\
\hline $\mathrm{Aa}$ & 10 & 22 & $\begin{array}{c}1.2 \\
(0.5-2.7)\end{array}$ & 0.6 & $\begin{array}{c}1.1 \\
(0.4-2.6)\end{array}$ & 0.7 \\
\hline Frequency of a allel & $\begin{array}{c}36 \\
35.2 \%\end{array}$ & $\begin{array}{c}60 \\
30.9 \%\end{array}$ & $\begin{array}{c}0.8 \\
(0.5-1.4)\end{array}$ & 0.6 & & \\
\hline
\end{tabular}


DOI: https://doi.org/10.32792/utq/utjmed/18/2/4

Table 2: Results of genotype and allele frequency of eNOS gene polymorphism in patient and +ve control groups.

\begin{tabular}{|c|c|c|c|c|c|c|}
\hline $\begin{array}{l}\text { eNOS } \\
(\mathrm{a} / \mathrm{b})\end{array}$ & $\begin{array}{l}\text { Control } \\
+ \text { ve } \\
\mathbf{n}=48\end{array}$ & $\begin{array}{l}\text { DN } \\
\mathbf{n}=97\end{array}$ & $\begin{array}{c}\text { Unadjusted } \\
\text { OR } \\
(95 \% \mathrm{CI})\end{array}$ & $\begin{array}{c}\mathbf{P} \\
\text { value }\end{array}$ & $\begin{array}{c}\text { Adjusted } \\
\text { OR } \\
(95 \% \mathrm{CI})\end{array}$ & $\begin{array}{c}\mathbf{P} \\
\text { value }\end{array}$ \\
\hline \multicolumn{7}{|l|}{ Codominant } \\
\hline bb(Reference) & 10 & 16 & & & & \multirow[b]{2}{*}{0.52} \\
\hline $\mathrm{Ab}$ & 28 & 56 & $\begin{array}{c}0.54 \\
(0.23-1.25)\end{array}$ & 0.15 & $\begin{array}{c}0.75 \\
(0.3-1.8)\end{array}$ & \\
\hline $\mathrm{Aa}$ & 10 & 25 & $\begin{array}{c}1.25 \\
(0.49-3.18)\end{array}$ & 0.63 & $\begin{array}{c}2.63 \\
(0.8-7.9)\end{array}$ & 0.08 \\
\hline \multicolumn{7}{|l|}{ Dominant } \\
\hline$a a+a b$ & 23 & 40 & $\begin{array}{c}0.7 \\
(0.3-1.5)\end{array}$ & 0.5 & $\begin{array}{l}0.6 \\
(0.3-1.4)\end{array}$ & 0.3 \\
\hline \multicolumn{7}{|l|}{ Recessive } \\
\hline$a b+b b$ & 41 & 75 & & & & \\
\hline aa & 7 & 22 & $\begin{array}{c}1.7 \\
(0.6-4.3)\end{array}$ & 0.2 & $\begin{array}{c}1.5 \\
(0.6-4.2)\end{array}$ & 0.3 \\
\hline $\begin{array}{l}\text { Frequency of a } \\
\text { allel }\end{array}$ & $\begin{array}{c}29 \\
30.2 \%\end{array}$ & $\begin{array}{c}60 \\
30.9 \%\end{array}$ & $\begin{array}{c}0.08 \\
(0.6-1.8)\end{array}$ & 0.7 & & \\
\hline
\end{tabular}

Table 3:The distribution of the eNOS genotypes

\begin{tabular}{lccc}
\hline & bb & ab & aa \\
\hline Cases N=97 & $58.7 \%(57)$ & $18.5 \%(18)$ & $21.6 \%(21)$ \\
Control N=51 & $49 \%(25)$ & $31.3 \%(16)$ & $19.6 \%(10)$ \\
\hline
\end{tabular}

\section{Discussion}

SNPs of eNOS(VNTR) genes in patients and control group

Why some diabetic patients develop nephropathy, whereas others do not, despite having a long-term hyperglycemia , remains an unresolved problem. Because known environmental factors do not fully explain this, researchers have sought the answer at the genetic background of the host.

In our study the eNOS gene bb is the most frequent allele which present in $57.9 \%$, followed by aa then ab $(21.6 \%$ and $18.5 \%$ ) respectively. While Neugebauer et $\mathrm{al}^{(19)}$ the frequency of $\mathrm{bb}, \mathrm{ab}$, and aa genotypes in patients are
$69.2 \%, 23.0 \%$ and $8 \%$, respectively. In cocasian populations the frequency of $\mathrm{bb}, \mathrm{ab}$, and aa genotypes are $72.1 \%$, $26.9 \%$, and $1 \%$ respectively ${ }^{(20)}$.

However, genotype frequencies of eNOS gene were deviated from Hardy-Weinberg equilibrium in control persons and $\mathrm{DN}$ subjects $(\mathrm{P}=$ 0.000). Previously, Ksiasek et al (21) have reported such observation but others ( 22, 20 ) have confirmed consistence with HWE. The deviation from HWE may be attributed to the small sample size of our study ${ }^{(23)}$.

The calculated genetic power to detect a significant difference at level 
ISSN (Print):1992-92 18, ISSN (Online):1992-92 18

DOI: https://doi.org/10.32792/utq/utjmed/18/2/4

of 0.05 for eNOS was $79.9 \%$ with $\mathrm{DN}$ in other studies $(5,19,22,25,26)$. respectively, which is seemed to be the current investigation did not reveal greater than the optimal level $(80 \%)$.

The MAF of eNOS in the normal control group $(35.2 \%)$ while in the diabetic control $(30.2 \%)$ which higher than Japanese population $(7.1 \%, 7.3 \%)$ respectively (19) , and Poland people $(0.14 \%) \quad$ (24) $\quad$ Germany ${ }^{(20)}$,Tunisia $(23.24 \%)^{(22)}$, East-Asian (India) $(13.9 \%)^{(25)}$.

Results of eNOS gene polymorphism did not reveal significant difference in the distributions among patients and the control group these results are consistent with studies of Egyptian ${ }^{(26)}$, East Asian ${ }^{(22)}$, Chinese ${ }^{(27)}$,Iranian ${ }^{(28)}$, Japanese population ${ }^{(29)}$.

Although there is evident association of eNOS (VNTR) gene polymorphism

\section{References}

1. Rambhade S., Chakraborty A. K., Patil U. K., et al. Diabetes Mellitus- Its complications, factors influencing complications and prevention- An Overview. J. Chem. Pharm. Res., 2010, 2(6):7-25.

2. Phillip MH. Prevention of Progression in Diabetic Nephropathy

Diabetes Spectrum. 2006; 19(1): 18-24.

3. Forbes J M, Fukami K, Cooper M E. Diabetic Nephropathy: Where Hemodynamics Meets Metabolism. Exp Clin Endocrinol Diabetes 2007; 00:1 $-16$.

4. Edmund JL Xiulong, X . Abnormal glomerular permeability characteristics in diabetic nephropathy: Implication for the therapeutic use of the low-molecular weight heparin Diabetes Care.2008; 31(2): S202-S207.

5. Dellamea B S, Ferreira Pinto L C, Leitão C B,et al. Endothelial nitric oxide synthase gene polymorphisms and risk of diabetic nephropathy: a systematic review and meta-analysis. BMC Medical Genetics. 2014, 15:9 .

6. Bredt DS, Snyder SH: Nitric oxide: a physiologic messenger molecule. Annu Rev Biochem 1994, 63:175-195.

7. Tsutsui M, et al: Nitric oxide synthases and cardiovascular diseases: insights from genetically modified mice. Circ J 2009, 73(6):986-993.

8. Napoli C, Ignarro LJ: Nitric oxide and pathogenic mechanisms involved in the development of vascular diseases. Arch Pharm Res 2009, 32(8):1103-1108. 
ISSN (Print):1992-92 18, ISSN (Online):1992-92 18

DOI: https://doi.org/10.32792/utq/utjmed/18/2/4

9. Huang PL: eNOS, metabolic syndrome and cardiovascular disease. Trends Endocrinol Metab .2009;20(6):295-302.

10. MA Z, Chen R, Ren H, et al. Endothelial nitric oxide synthase (eNOS) 4b/a polymorphism and the risk of diabetic nephropathy in type 2 diabetes mellitus: A meta-analysis. Meta Gene . (2014);2: 50-62.

11. Yoon Y, Song J, Hong SH, Kim JQ. Plasma nitric oxide concentrations and nitric oxide synthase gene polymorphisms in coronary artery disease. Clin Chem .2000; 46: 1626-30.

12. Wang XL, Mahaney MC, Sim AS, et al. Genetic contribution of the endothelial constitutive nitric oxide synthase gene to plasma nitric oxide levels. Arterioscler Thromb Vasc Biol .1997; 17: 3147-53.

13. Bolli P, Sticchi E, Abbate R,et al . A novel allele of eNOS gene in the Italian population: the actual essence of intron 4 polymorphism. Nitric Oxide. 2007; 16: 392-4.

14. www.genecards.org.

15. Volgelstein, B., and Gillespie, D.(1979) Pro. Natl. Acad. Sci. USA 76.

16. Thompson, Margaret W., Roderick R. McInnes, and Huntington F. Willard. 1991. Thompson \& Thompson genetics in medicine. Fifth ed. Philadelphia: W. B. Saunders.

17. osse.bii.a-star.edu.sg.

18. Shah V N, Cheema B S, Kohli H S, et al. Endothelial Nitric Oxide Synthase Gene polymorphism and the risk of diabetic Neuropathy in Asian Indian Patients with Type 2 Diabetes. 2013. J Diabetes Metab. 4.2.

19. Neugebauer S, Baba T, and Watanabe T. Association of the Nitric Oxide Synthase Gene Polymorphism With an Increased Risk for Progression to Diabetic Nephropathy in Type 2 Diabetes. Diabetes. 2000: 49 :500-5030.

20. Bernhard Degen, Susanne Schmidt, Eberhard Ritz. A polymorphism in the gene for the endothelial nitric oxide synthase and diabetic nephropathy. Nephro Dia Transplant .2001.16:185-198.

21. Ksiazek P, et al: Endothelial nitric oxide synthase gene intron 4 polymorphism in type 2 diabetes mellitus. Mol Diagn 2003, 7(2):119-123.

22. Ezzidi I, Mtiraoui N, Mohamed MBH, et al. Association of endothelial nitric oxide synthase Glu298Asp, 4b/a, and $-786 \mathrm{~T}>\mathrm{C}$ gene variants with diabetic nephropathy. J Diabetes Complications. 2008; 22(5):331-338.

23. Elias Zintzaras Impact of Hardy-Weinberg equilibrium deviation on allelebased risk effect of genetic association studies and meta-analyses, European Journal of Epidemiology 25, 8 (2010) 553-560.

24. Buraczynska M, Ksiazek P, Zaluska W, et al. Endothelial nitric oxide synthase gene intron 4 polymorphism in patients with end-stage renal disease. Nephrol Dial Transplant (2004) 19: 2302-2306. 
ISSN (Print):1992-92 18, ISSN (Online):1992-92 18

DOI: https://doi.org/10.32792/utq/utjmed/18/2/4

25. Ahluwalia, T. S., Ahuja, M., Rai, T. S., Kohli, H. S., Sud, K., Bhansali, A. and Khullar, M. Endothelial nitric oxide synthase gene haplotypesand diabetic nephropathy among Asian Indians. Mol. Cell Biochem.2008;314, 9-17.

26. ShoukryA, Shalaby S M, Abdelazim S,et al. Endothelial Nitric Oxide Synthase Gene Polymorphisms and the Risk of Diabetic Nephropathy in Type 2 Diabetes Mellitus. Genetic Testing and Molecular Biomarkers.2012;16(6): 574-579.

27. Lin S, Qu H, Qiu M. Allele A in intron 4 of ecNOS gene will not increase the risk of DN in type 2 diabetes of Chinese population. Nephron.2002; 91:768.

28. Rahimi, Z., Rahimi, Z., Shahvaisi-Zadeh, F., Sadeghei, S., Vessal, M., Yavari, N., 2013. eNOS 4a/b polymorphism and its interaction with eNOS G894T variants in type 2 diabetes mellitus: modifying the risk of diabetic nephropathy. Dis. Markers.2013; 34, 437-443.

29. Taniwaki H, Ishimura E, Matsumoto N, et al. Relations Between ACE Gene and ecNOS Gene Polymorphisms and Resistive Index in Type 2 Diabetic Patients With Nephropathy. Diabetes Care .2001;24:1653-1660.

\section{علاقة اوكسيد النتريك جين (VNTR) مع خطر اعتلال الكلية السكري

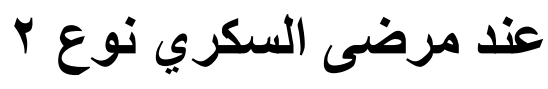 \\ م. احمد جلال محمد

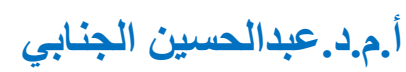 \\ م.د.لميس ماجدالجنابي}

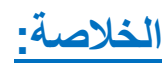

إعتلال الكلى السكري (DN) يشكل مشكلة صحية كبيرة .هنالك أدلة قوية على وجود دور محتمل

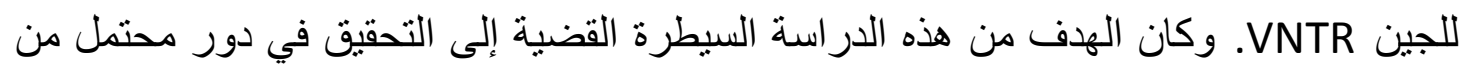

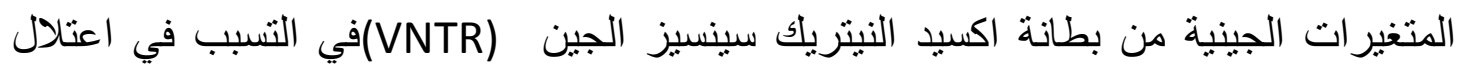

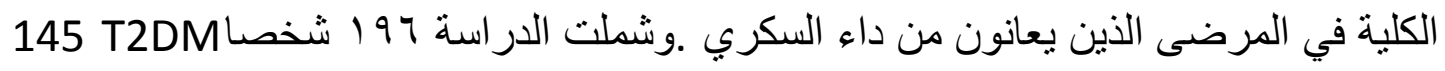

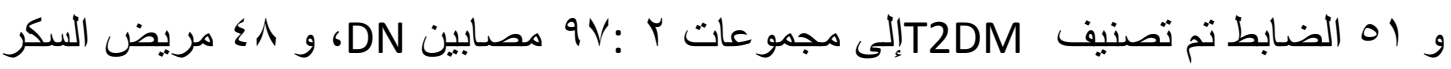

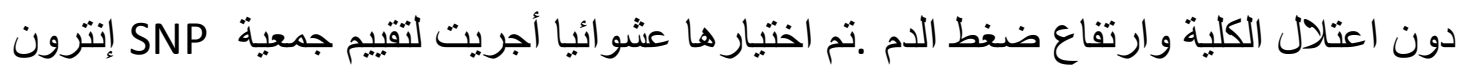
تعNTR 4a /4b

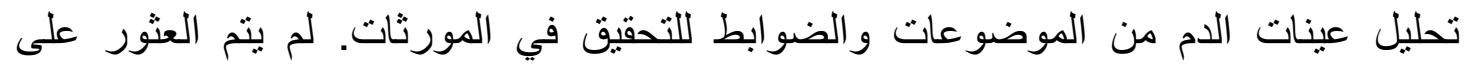

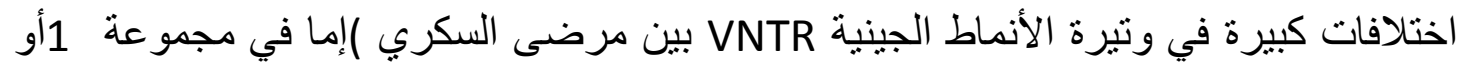

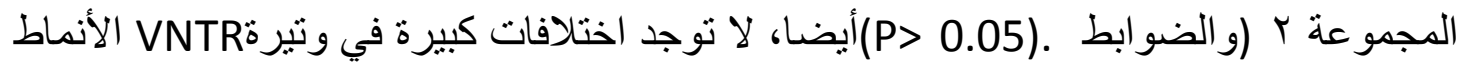

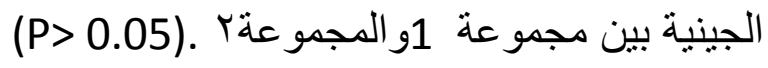

